DOI: 10.15679/bjwr.v3i1.32

\title{
ADVANCEMENT REPORT ON POPULATION GENETIC STUDY OF BROWN HARE POPULATIONS IN CENTRAL AND EASTERN EUROPEAN REGION
}

\begin{abstract}
Soós N. ${ }^{1}$, Djan, M. ${ }^{2}$, Kusza Sz. ${ }^{1}$
Summary: The brown hare is present all over Europe from Spain to Asia Minor and is an important game species which makes it a reasonable subject for population genetic investigations. The purpose of our study is to gather data on the genetic diversity of Central and Eastern European brown hare populations with the aim of revealing the genetic history of the species in the studied region, from which data are scarce despite the fact that the species is well-studied on the whole continent. In our research mtDNA cytb and D-loop regions along with the MC1R and ASIP genes are studied. Samples from Hungary $(\mathrm{n}=14)$ and Serbia $(\mathrm{n}=36)$ have already been sequenced and analysed for the D-loop region. Based on a 411 bp mtDNA D-loop alignment we have found a high level of haplotype diversity ( $\mathrm{Hd}=0.958)$ with an overall 30 haplotypes, and the nucleotide diversity of $\pi=0.0167$. Our first results show high genetic diversity for the brown hare in the studied region and indicate genetic distinction among the studied populations although these results need confirmation by further studies.
\end{abstract}

Key words: diversity, Central, Eastern Europe, Lepus europaeus, mitochondrial DNA

\section{Introduction}

The present phylogenetic status -distribution and diversity- of most European mammal species is eminently the result of the multiple climatic changes of the Pleistocene epoch. In the case of brown hares (Lepus europaeus Pallas 1778) among the abovementioned effects (Hewitt, 1999; Kasapidis et al., 2005; Alves et al., 2008) the fragmentation of natural habitats, hybridization among different Lepus species or competition for decreased food resources are also to be considered (Tapper and Barnes, 1986; Endler and Jezierski, 1995; Panek and Kamieniarz, 1999;). The species is present all over Europe which is why many researches focused on its phylogeography (Kasapidis et al. 2005; Stamatis et al., 2009; Antoniou et al., 2013), however there are discrepancies regarding its glacial refugia and expansion directions. Some studies indicate that there was one refugium on the Balkan-peninsula for the majority of Europe's brown hares (Stamatis et al., 2009), while others suggest the past existence of multiple refugia along the Mediterranean region to which the brown hares could withdraw during the last glacial maximum (Kasapidis et al., 2005; Fickel et al., 2008). Several mitochondrial DNA-based diversity studies have been carried out on L. europaeus populations over the last decades using typically the D-loop and cytochrome-b regions of the mtDNA molecule (Alves et al., 2003; Kasapidis et al., 2005; Djan et al., 2006; Stamatis et al., 2009; Mamuris et al., 2010). These researches have shown genetic divergence of different degree among the brown hare populations of Europe. A very high level of haplotype diversity ( $h=0.853$ ) with a great number of haplotypes has been described from Greece by Mamuris et al. (2001). The haplotype diversity of brown hares of Vojvodina was found to be $\mathrm{Hd}=0.34$ (Djan et al., 2006), while in some other regions of Central Europe there has been described the expressly low value of $\mathrm{Hd}=0.158$ (Hartl et al., 1993).

\footnotetext{
${ }^{1}$ Noémi Soós, PhD, Kusza Szilvia PhD,Institute of Animal Science, Biotechnology and Nature Conservation, University of Debrecen, Böszörményi str. 138., 4032 Debrecen, Hungary;

${ }^{2}$ Mihajla Djan, PhD, Associate professor University of Novi Sad, Faculty of Sciences, Department of Biology and Ecology, Trg Dositeja Obradovica 2, 21000 Novi Sad, Serbia
}

Corresponding author: Noémi Soós, soos.noemi@agr.unideb.hu 
Though these studies have provided a large amount of data on L. europaeus populations of the continent we have few information about the ones in Central and Eastern Europe. For this reason we intend to define the genetic diversity of Central and Eastern European brown hare populations, describing the genetic history (including possible glacial refugia) of the species in the studied region and revealing genetic relationships with other populations of the continent. Molecular genetic studies make reachable raw data for conservation biology researches. This provides the possibility of further analyzing important diversity related topics which can be crucial in creating successful sustainable management plans for wild animal species. This is the most important when species representing economic value are of concern, as in case of the brown hare.

Here we provide preliminary results regarding the Central and Eastern European hare populations' mtDNA diversity.

\section{Material and Methods}

\section{Sample collection and preparation}

In this study, we present data for fifty samples of which 14 are from Hungary and 36 from Serbia from 19 sampling locations altogether (Figure 1.). They have been collected during the hunting seasons of 20112014.

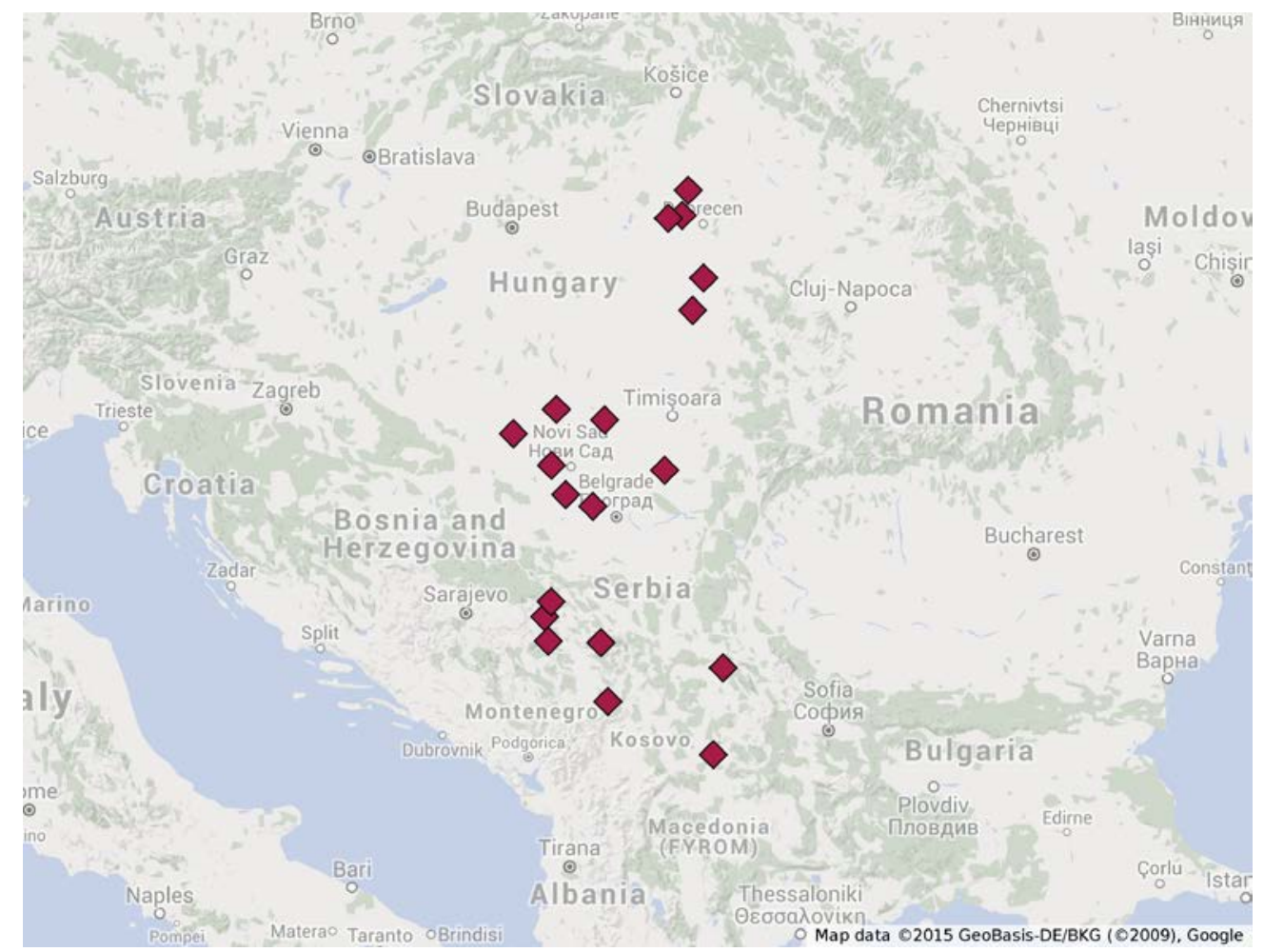

Figure 1. Map of the 19 sampling locations in Hungary $(s \mathrm{l}=5)$ and Serbia $(\mathrm{sl}=14)$.

The sample preparation was carried out following the protocol E.Z.N.A.® Tissue DNA Kit (Omega BioTek) in case of the tissue samples. Nucleic acid from hair follicles was isolated with and following the instructions of Sigma-Aldrich's ProteinaseK from Tritirachium album. After isolation we amplified a 518 base pairs long sequence of the D-loop region under the following conditions: initial denaturation at $94{ }^{\circ} \mathrm{C} / 5$ min, followed by 35 cycles of $94{ }^{\circ} \mathrm{C} / 1 \mathrm{~min}, 60^{\circ} \mathrm{C} / 1 \mathrm{~min}$, and $72^{\circ} \mathrm{C} / 1 \mathrm{~min}$, and a final cycle at $72{ }^{\circ} \mathrm{C}$ for 5 
min. The electrophoretic pattern was visualized by ethidium bromide in $2 \%$ agarose gel. After checking we have had the PCR product purified and sequenced as a service.

\section{Sequence analysis}

Sequences were aligned using CodonCode Aligner (CodonCode Corporation, www.codoncode.com) and checked by bare eye. We have proceeded the analyses with two different alignments: 411 bp alignment of our 50 samples and a $333 \mathrm{bp}$ alignment of our samples and $156 \mathrm{~L}$. europaeus sequences downloaded from GenBank along with an Oryctolagus cuniculus (Linnaeus 1758) (Accession number: AJ535793) sequence which was used as an outgroup for a phylogenetic tree. DnaSP 5.10 was used to calculate main diversity indices (Rozas et al., 2003; Librado and Rozas, 2009). The software determines the number of haplotypes and calculates haplotype diversity $(\mathrm{Hd})$ and nucleotide diversity $(\pi)$ values following Nei's method (Nei, 1987; Nei and Miller, 1990). After testing the most fitting model a maximum-likelihood tree was generated with MEGA 6.06 software (Tamura et al., 2013) using the Hasegawa-Kishino-Yano model $(G+I)$ which model allows different substitution rates (one transition and one transversion rate) (Hasegawa et al., 1985).

\section{Results}

A total of 30 haplotypes were revealed among the $50 \mathrm{~L}$. europaeus mtDNA D-loop sequences from Hungary and Serbia, and the haplotype diversity was found to be $\mathrm{Hd}=0.958( \pm 0.018)$. Most of the haplotypes represent a single sample (20/30) while one of them (H15) consists of nine individuals' sequences (Table 2.). Though there were haplotypes (2/30) which consisted of sequences of both Hungarian and Serbian individuals a definite distinction can be observed between the two country's populations. The nucleotide diversity was $\pi=0.0167$ with 54 polymorphic sites (Table 3.). Inclusion of the GenBank sequences did not result in alteration of the haplotype diversity value however it did affect the nucleotide diversity and the number of polymorphic sites (Table 1.).

Table 1: Diversity indices of L. europeaus populations in two alignments of our study

\begin{tabular}{l|c|c}
\multicolumn{1}{c|}{ Initial results } & Our samples & $\begin{array}{c}\text { Our samples and 156 } \\
\text { GenBank sequences }\end{array}$ \\
\hline Number of samples & 50 & 206 \\
\hline Number of detected haplotypes & 30 & 127 \\
\hline Haplotype diversity $(\mathrm{Hd})$ & $0.9584 \pm 0.018$ & $0.9857 \pm 0.004$ \\
\hline Nucleotide diversity $(\pi)$ & $0.0167 \pm 0.0016$ & $0.0464 \pm 0.0026$ \\
\hline Number of polymorphic sites & 54 & 124
\end{tabular}

The constructed maximum-likelihood tree (HKY $(G+I)$ shows a distinction between our samples and German (except for 5 samples), Austrian or Italian ones while indicates a much closer relation with those from Greece (Figure 2.). 
Table 2. Number and origin of the samples of our study for each haplotype

\begin{tabular}{ccc|ccc} 
Haplotype & $\begin{array}{c}\text { No. of } \\
\text { samples }\end{array}$ & $\begin{array}{c}\text { Origin of } \\
\text { samples }\end{array}$ & Haplotype & $\begin{array}{c}\text { No. of } \\
\text { samples }\end{array}$ & $\begin{array}{c}\text { Origin of } \\
\text { samples }\end{array}$ \\
\hline H1 & 3 & SER & H16 & 1 & SER \\
H2 & 1 & SER & H17 & 2 & HUN, SER \\
H3 & 2 & SER & H18 & 1 & SER \\
H4 & 1 & SER & H19 & 1 & SER \\
H5 & 2 & SER & H20 & 1 & SER \\
H6 & 1 & SER & H21 & 1 & SER \\
H7 & 2 & SER & H22 & 3 & SER \\
H8 & 1 & SER & H23 & 1 & SER \\
H9 & 2 & SER & H24 & 1 & SER \\
H10 & 1 & SER & H25 & 1 & SER \\
H11 & 1 & SER & H26 & 1 & SER \\
H12 & 1 & SER & H27 & 2 & HUN \\
H13 & 1 & SER & H28 & 3 & HUN \\
H14 & 1 & SER & H29 & 1 & HUN \\
H15 & 9 & HUN, SER & H30 & 1 & HUN
\end{tabular}

\section{Discussion}

Although molecular genetic studies on brown hare have provided a wide range of data on diversity, phylogeny and different evolutionary processes of this species from all over Europe we do not have much information regarding the L. europaeus populations of the Central and Eastern-European regions. Researches took place in Austria (Hartl et al., 1993) and the region of Vojvodina in Serbia (Vapa et al., 2002; Djan et al., 2004, 2006; Vapa et al., 2007) but apart from a few known haplotypes (Pierpaoli et al., 1999) no information is acceptable on the diversity of Hungarian populations so far.

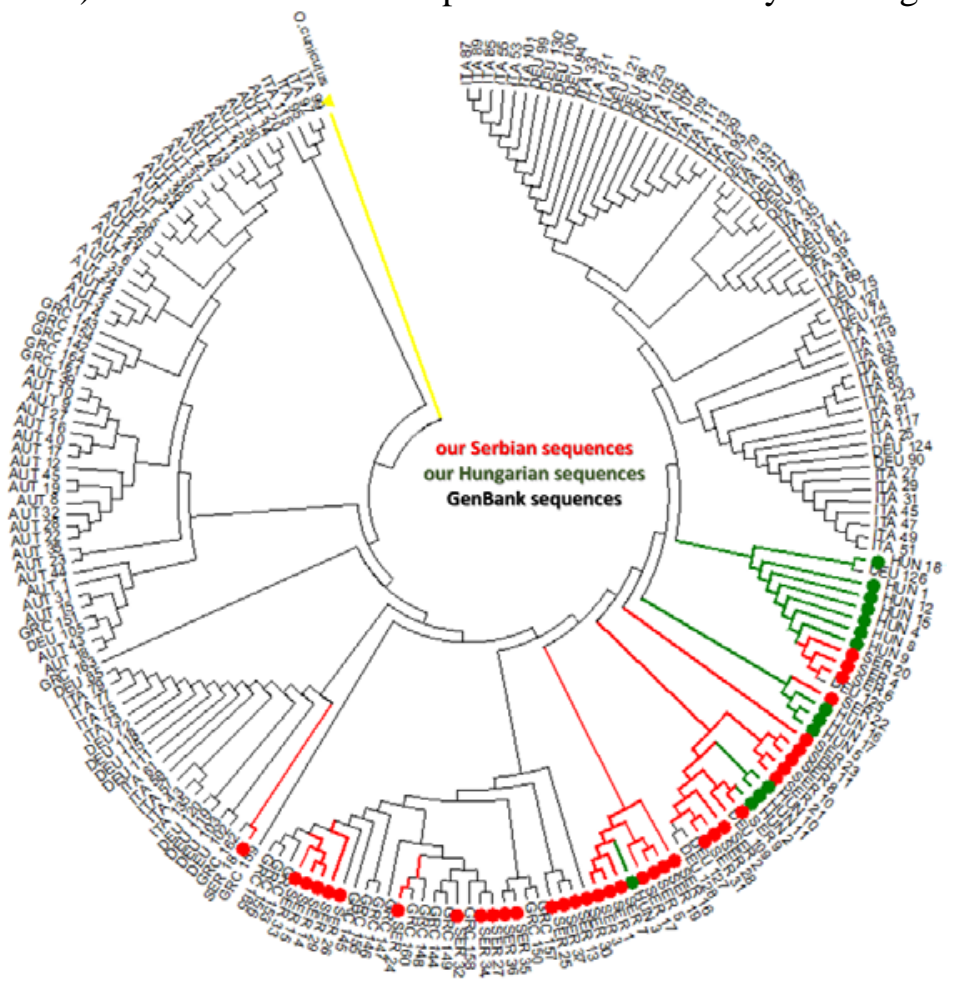

Figure 2. Maximum-likelihood tree (HKY) of 206 L. europaeus mtDNA D-loop sequences. Oryctolagus cuniculus (Acc. no.: AJ535793) as outgroup. 
Therefore our aim was to investigate the present diversity status and the phylogeny of the species in the Carpathian-basin where it is an economically important game species. The high haplotype diversity we have found is in congruence with those described for the brown hare in previous studies from most of the populations in Europe. Fickel et al. (2008) for instance determined the main diversity indices separately for four geographic areas of the continent and described similarly high haplotype diversity values for populations in Italy $(\mathrm{Hd}=0,932)$, Central Europe $(\mathrm{Hd}=0,926)$, the Balkans $(\mathrm{Hd}=0,99)$ and Asia Minor $(\mathrm{Hd}=0,948)$. Their results have been supported by Mengoni (2011) who found the Hd value of Italian brown hares to be 0,942 . As previously mentioned Mamuris et al. (2008) described the haplotype diversity of $\mathrm{Hd}=0,853$ in Greece which is slightly lower than the abovementioned values though they included reared individuals in their study (24/210). Andersen et al. (2009) published that the Hd value of Danish brown hare populations ranged between zero (in one of the populations only one haplotype has been found) and $\mathrm{Hd}=0,82$. The Hd values of brown hare populations in Central Europe were reported to be expressly lower than in other regions of Europe. In contradiction with our $\mathrm{Hd}=0,958$ value Djan et al. (2006) found a haplotype diversity of $\mathrm{Hd}=0.34$ in Vojvodina, while in Austrian populations $\mathrm{Hd}=0.158$ has been described by Hartl et al. (1993).

As for the genetic relationships between populations the first results of our large-scale study show that Hungarian samples are related to both Serbian and Greek ones however most of them are definitely separable from GenBank sequences from other geographical regions (Fig. 2.). This indicates that both the Serbian and Hungarian brown hares may have expanded from the main glacial refugium area of the Balkanpeninsula and Greece.

This pattern is in contradiction with the one described in Fickel et al. (2008) where the Central European brown hares show a closer genetic relationship with the Italian populations indicating that they re-colonized the Central European region from Italian ancestry over post-glacial times.

Our multi-year research aims to describe the diversity and reveal the origin of L. europaeus populations of the Carpathian-basin to help to understand more deeply the shaping factors of genetic structure of the species in the region. This might help in preservation and management which is crucial in keeping genetic variability at high level regarding species that live in shrinking natural habitats and are as over-hunted and translocated over the times as the brown hare.

\section{Acknowledgment}

This work was supported by the János Bolyai Research Scholarship of the Hungarian Academy of Sciences. 
Table 3: Polymorphic sites of the 30 different haplotypes found in this study

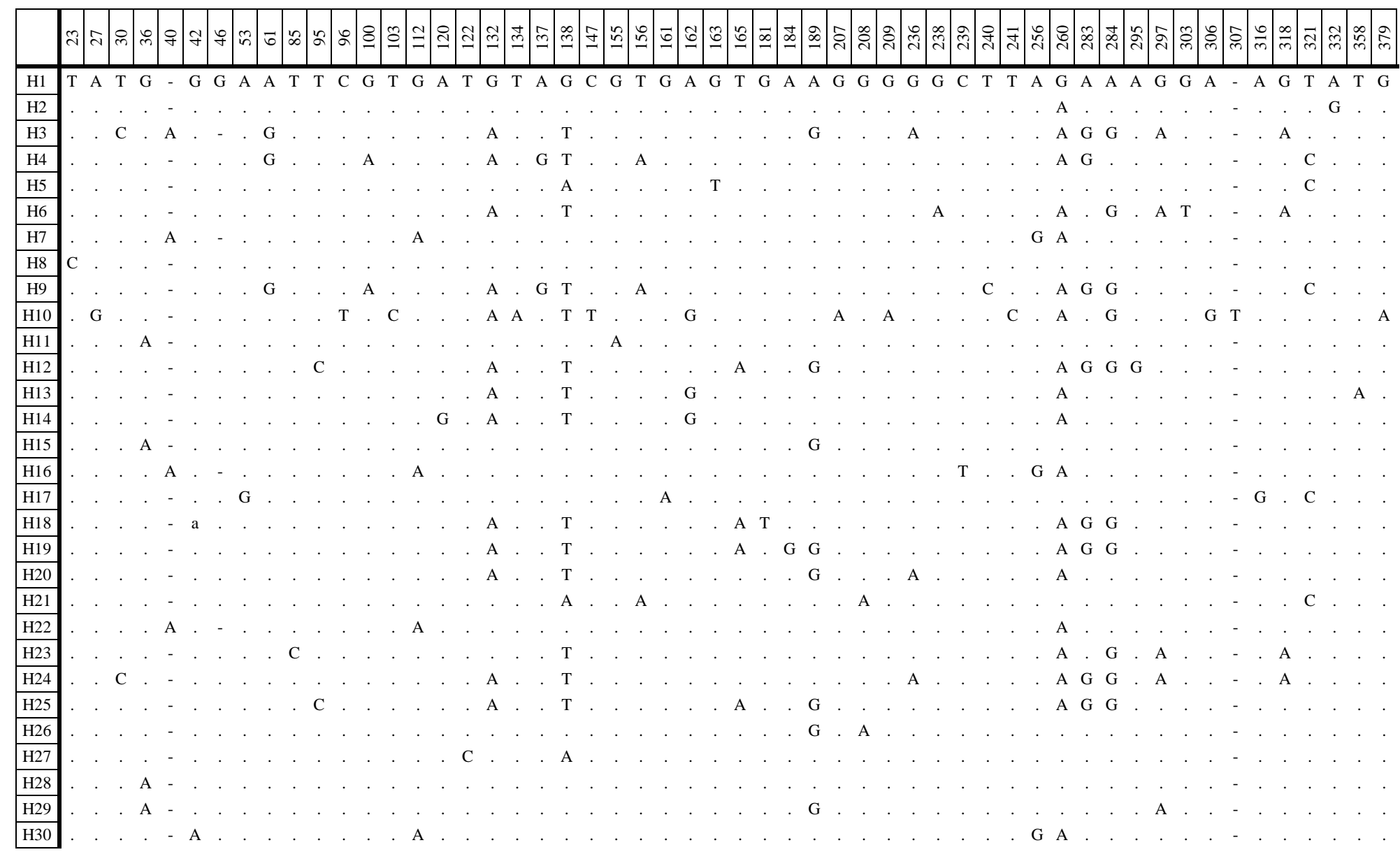




\section{References}

1. Alves P.C., Ferrand N., Suchentrunk F., Harris D.J. (2003) Ancient introgression of Lepus timidus mtDNA into L. granatensis and L. europaeus in the Iberian Peninsula, Molecular Phylogenetics and Evolution, 27 pp. 70-80.

2. Alves P.C., Melo-Ferreira J., Branco M., Suchentrunk F., Ferrand N., Harris D.J. (2008) Evidence for genetic similarity of two allopatric European hares (Lepus corsicanus and L. castroviejoi) inferred from nuclear DNA sequences, Molecular Phylogenetics and Evolution, 46 pp. 1191-1197.

3. Andersen L.W., Fredsted T., Wincentz T., Pertoldi C. (2009) Brown hares on the edge: Genetic population structure of the Danish brown hare, Acta Theriologica, 54 (2), pp. 97-110.

4. Antoniou A., Magoulas A., Platis P., Kotoulas G. (2013) Assessing the genetic landscape of a contact zone: the case of European hare in northeastern Greece, Genetica, 141, pp. 23-40.

5. Djan M.R., Vapa L.B., Obreht D.R., Vapa M.M., Šelmić V.R. (2004) On gene pool divergence of the brown hare (Lepus europaeus, Pallas) in Vojvodina, Proc. Nat. Sci. Matica Srpska Novi Sad, 107, pp. 13-20.

6. Djan M., Obreht D., Vapa L. (2006) Polymorphism of mtDNA regions in brown hare (Lepus europaeus) populations from Vojvodina (Serbia and Montenegro), European Journal of Wildlife Research, 52, pp. 288-291.

7. Endler Z., Jezierski W. (1995) The structure of habitats and the diet of hares. In: Hare - International Symposium, Czempiń 1992., pp. 231-245. Polski Związek Łowiecki, Warszawa. (In Polish)

8. Fickel J., Hauffe H.C., Pecchioli E., Soriguer R., Vapa L., Pitra C. (2008) Cladogenesis of the European brown hare (Lepus europaeus Pallas, 1778), European Journal of Wildlife Research, 54, pp. 495-510.

9. Hartl G.B., Suchentrunk F., Nadlinger K., Willing R. (1993) An integrative analysis of genetic differentiation in the brown hare Lepus europaeus based on morphology, allozymes, and mitochondrial DNA, Acta Theriologica, 38(2), pp. 33-57.

10.Hasegawa M, Kishino H, Yano T (1985) Dating of human-ape splitting by a molecular clock of mitochondrial DNA, Journal of Molecular Evolution, 22(2), 160-174.

11.Hewitt G.M. (1999) Postglacial re-colonization of European biota. Biological Journal of the Linnean Society, 68, pp. 87112.

12.Kasapidis P., Suchentrunk F., Magoulas A., Kotoulas G. (2005) The shaping of mitochondrial DNA phylogeographic patterns of the brown hare (Lepus europaeus) under the combined influence of Late Pleistocene climatic fluctuations and anthropogenic translocations, Molecular Phylogenetics and Evolution, 34, pp. 55-66.

13.Librado, P. and Rozas, J. (2009) DnaSP v5: A software for comprehensive analysis of DNA polymorphism data, Bioinformatics, 25, pp. 1451-1452.

14.Mamuris Z., Sfougaris A.I., Stamatis C. (2001) Genetic structure of Greek brown hare (Lepus europaeus) populations as revealed by mtDBNA RFLP-PCR analysis: Implications for conserving genetic diversity, Biological Conservation, 101(2), pp. 187-196.

15.Mamuris Z., Moutou K.A., Stamatis C., Sarafidou Th., Suchentrunk F. (2010) Y DNA and mitochondrial lineages in European and Asian populations of the brown hare (Lepus europaeus), Mammalian Biology, 75, pp. 233-242.

16.Mengoni C. (2011): Phylogeny and genetic diversity of Italian species of hares (genus Lepus). Ph.D. thesis. University of Bologna, Italy.

17.Nei M. (1987) Molecular Evolutionary Genetics. Columbia University Press, New York.

18.Nei M. and J. C. MILLER (1990) A simple method for estimating average number of nucleotide substitutions within and between populations from restriction data. Genetics 125: 873-879.

19.Panek M., Kamieniarz R. (1999) Relationships between density of Brown hare (Lepus europaeus) and landscape structure in Poland in years 1981-95, Acta Theriologica, 44, pp. 67-75.

20.Pierpaoli M., Riga F., Trocchi V., Randi E. (1999) Species distinction and evolutionary relationships of the Italian hare (Lepus corsicanus) as described by mitochondrial DNA sequencing, Molecular Ecology, 8, pp. 1805 -1817.

21.Rozas, J., Sánchez-DelBarrio, J. C., Messeguer, X. and Rozas, R. (2003) DnaSP, DNA polymorphism analyses by the coalescent and other methods, Bioinformatics, 19 pp. 2496-2497.

22.Stamatis C., Suchentrunk F., Moutou K. A., Giacometti M., Haerer G., Djan M., Vapa L., Vukovic M., Tvrtković N., Sert H., Alves P. C., Mamuris Z. (2009) Phylogeography of the brown hare (Lepus europaeus) in Europe: a legacy of southeastern Mediterranean refugia?, Journal of Biogeography, 36, pp. 515-528.

23.Tamura K., Stecher G., Peterson D., Filipski A., Kumar S. (2013) MEGA6: Molecular Evolutionary Genetics Analysis Version 6.0., Molecular Biology and Evolution, 30, pp. 2725-2729.

24.Tapper S.C., Barnes R.F.W. (1986) Influence of farming practice on the ecology of the brown hare (Lepus europaeus), Journal of Applied Ecology, 23, pp. 39-52.

25.Vapa L., Obreht D., Vapa M., Selmic V. (2002) Genetic variability in brown hare (Lepus europaeus) populations in Yugoslavia. Zeitschrift Fur Jagdwissenschaft 48, pp. 261-266.

26.Vapa L., Djan M., Obreht D., Hammer S., Suchentrunk F. (2007) Allozyme variability of brown hares (Lepus europaeus) from the Vojvodina (Serbia), compared to central and south eastern European populations, Acta Zoologica Academiae Scientiarum Hungaricae, 53, pp. 75-87.

Received: 15.10.2015.

Accepted: 11.03.2016.

Soós N. Djan, M. Kusza Sz. (2016) Advancement report on population genetic study of brown hare populations in Central and Eastern European region. Balkan Journal of Wildlife Research, 3(1), pp. 12-18. 